\title{
Research on the Relationship of Rural Financial Development Efficiency and Income Growth of Farmers
}

Wang Qianfei ,Li He

\section{Northeast Agricultural University Harbin , Heilongjiang Province 150030}

Abstract: Byusing vector error correction model (VECM)with control variables and Granger causality test method, correlation and causationof rural financial development and income growth among farmers are re-examined. The results show that in the long term, the scale, structure and efficiency of rural finance development exists co-integration with farmers' income and the rural investment. In the short term, the scale of development and increase of farmers' income rural finance growth has bidirectional Granger causality, while rural financial development structure and efficiency are not the Granger causes to farmers' income growth. Therefore, expanding the scale of rural financial development in favor of increasing farmers' income and promoting rural economic development are important. In addition, income growth of farmers and rural economic development can also promote the development of rural finance to some extent. Currently relatively low efficiency of China's rural credit allocation increases town business loans which is helpful to income growth of farmers.

Keywords: Rural finance development; Income growth of farmer; Vector error correction model; Granger causality test

\section{Introduction}

Rural financial development is an important factor to promote rural economic growth and increase farmers' income. The financial impact of revenue is primarily reflected in two aspects. The first is to promote rapid economic growth, and the second is to change the pattern of income distribution. From this perspective, the rural financial development can relieve credit constraints of farmers and promote the allocation of funds to accelerate economic growth as well.
The relevant study of rural financial development, rural economic growth and the relationship between the growths of farmers' income is mainly divided into the following three categories.By studying the relationship between rural financial development and rural economic growth and the relationship between the general financial development and economic growth, most scholars come to a conclusion that the relationship is positive. Many scholars have put forward some measures to promote rural economic development or rural financial development, to enable farmers' income growth.

From the perspective of rural finance development of urban-rural income gap, some of the scholars have studied indirectly and received the relationship between financial development and farmers' income growth.

Another part of the scholars make researches on the relationship between development and farmers' income growth and make rural finance empirical research. Such research has long been implicit in the study of rural financial development and rural economic growth, the financial development and farmers' income growth is a natural relationship between financial development positive correlations between economic growths. Some analysis show that: in the long term, the relationship does not exist between the income of farmers and rural financial institutions, in the short term, whether rural, rural financial institutions or credit ratios have not become household savings which causes farmers' income growth. Some scholars used the level of per capita household financial savings on behalf of rural development to establish the relationship between financial development and rural farmers' income 
growth and concluded that there was a significant correlation between the rural finance development and farmers' income growth, and presented complex bidirectional causality.

\section{Empirical Analysis}

To avoid spurious regression, this paper will first use ADF unit root test method to test the stability of each variable, for non-stationary variables are processed to become stationary time series. If the variable is a single whole, we will make co-integration test in order to determine the long-term relationship between the rural finance development and farmers' income growth. The co-integration lessons learned only that there is a correlation equation or at least one direction of causality between variables. Causal relationship between variables required causality test. VAR models are based on this impulse response function analysis to determine the impact on the development of rural finance farmers' income growth.

\subsection{Unit root test}

Use Eviews5.0, take ADF test method to make level values and a first-order differential value of each variable for unit root test. Test results are shown in Table 1 , where $\Delta \mathrm{FR}, \Delta \mathrm{RLD}, \Delta \mathrm{RFIR}, \Delta \mathrm{RFI}$ and $\Delta \mathrm{RLTL}$ denote the first difference of each variable, the inspection process to determine the lag using SIC principles. Through examination we can find that, FR, RLD, RFIR, RFI and RLTL are non-stationary variables, and all the first-order difference sequence in $5 \%$ significance level are smooth, and are also first-order single.

Tab 1 ADF test results

\begin{tabular}{c|c|c|c|c}
\hline Variable & Inspection form(C,T,L) & Test value & Significant levels (thresholds) & Conclusion \\
\hline FR & $(\mathrm{C}, \mathrm{T}, 1)$ & -2.7298 & $10 \%(-3.2381)$ & Not smooth \\
\hline$\Delta$ FR & $(\mathrm{C}, \mathrm{T}, 2)$ & -3.6515 & $5 \%(-3.6220)$ & Smooth \\
\hline RLD & $(\mathrm{C}, \mathrm{T}, 0)$ & -1.7760 & $10 \%(-3.2335)$ & Not smooth \\
\hline$\Delta$ RLD & $(\mathrm{C}, \mathrm{T}, 0)$ & -5.7240 & $1 \%(-4.3743)$ & Smooth \\
\hline RFI & $(\mathrm{C}, 0,1)$ & -2.1940 & $10 \%(-2.6326)$ & Not smooth \\
\hline \multirow{2}{*}{$\Delta$ RFI } & $(0,0,1)$ & -3.1849 & $1 \%(-2.6449)$ & Smooth \\
& $(\mathrm{C}, 0,1)$ & -3.1612 & $5 \%(-2.9919)$ & Smooth \\
\hline RFIR & $(\mathrm{C}, \mathrm{T}, 1)$ & -2.4734 & $10 \%(-3.2381)$ & Not smooth \\
\hline \multirow{2}{*}{$\Delta$ RFIR } & $(0,0,0)$ & -3.3483 & $1 \%(-2.6607)$ & Smooth \\
\hline RLTL & $(\mathrm{C}, 0,0)$ & -3.5997 & $5 \%(-2.9862)$ & Smooth \\
\hline$\Delta$ RLTL & $(0,0,0)$ & -1.4980 & $10 \%(-2.6299)$ & Smooth \\
\hline
\end{tabular}

\subsection{Co-integration test}

There may be some kind of smooth linear combination between the various indicators reflecting rural financial development, the level of investment in fixed assets and farmers' income growth in rural areas. In this paper, Johansen co-integration test is used to determine whether there is relationship between them. Through a series of tests for VAR model, we can find that the goodness of fit is very good, with a smooth residual sequence and it is indeed optimal model. Johansen co-integration test results can be seen in Table 2 . 
Tab 2 Johansen co-integration test results

\begin{tabular}{c|c|c|c}
\hline $\begin{array}{c}\text { HQ:The number of } \\
\text { cointegration vectors }\end{array}$ & Eigenvalues & $\begin{array}{c}\text { Trace } \\
\text { statistics }\end{array}$ & $\begin{array}{c}\text { Significance level of 5\% } \\
\text { critical value }\end{array}$ \\
\hline $\mathrm{r}=0$ & 0.999252 & 289.6069 & 69.81889 \\
\hline $\mathrm{r} \leq 1$ & 0.935809 & 116.8645 & 47.85613 \\
\hline $\mathrm{r} \leq 2$ & 0.720908 & 50.96312 & 29.79707 \\
\hline $\mathrm{r} \leq 3$ & 0.474369 & 20.33398 & 15.49471 \\
\hline $\mathrm{r} \leq 4$ & 0.184614 & 0.898246 & 3.841466 \\
\hline
\end{tabular}

\subsection{Granger causality test}

Use the equalization error correction model for rural finance development of various factors, the rate of fixed asset investment in rural areas and farmers' revenues Granger causality test. Error correction coefficient test shows that in the long-term, the scale, structure, farmers' income and rural fixed asset investment rural finance development is the reason of Granger (significance level $8.82 \%$ ), while farmers' income is weak with respect to long-term parameters exogenous variables. Table 3 shows the results of short-term test of causation.

Tab 3 Granger causation test

\begin{tabular}{|c|c|c|c|c|c|}
\hline Variable & Null hypothesis & $\begin{array}{l}\text { Best } \\
\text { lag }\end{array}$ & $\begin{array}{l}\text { Number of } \\
\text { samples }\end{array}$ & F statistics & Probability \\
\hline \multirow{2}{*}{$\Delta \mathrm{RFIR}$} & $\begin{array}{c}\Delta \mathrm{RFIR} \text { is not the Granger reason } \\
\text { for } \Delta \mathrm{FR}\end{array}$ & 3 & 24 & 5.26730 & 0.00941 \\
\hline & $\begin{array}{c}\Delta \mathrm{FR} \text { is not the Granger reason } \\
\text { for } \Delta \mathrm{RFR}\end{array}$ & 3 & 24 & 4.26161 & 0.02040 \\
\hline \multirow{2}{*}{$\Delta \mathrm{RLD}$} & $\begin{array}{c}\Delta \mathrm{RLD} \text { is not the Granger reason } \\
\text { for } \Delta \mathrm{FR}\end{array}$ & 3 & 24 & 0.50580 & 0.68345 \\
\hline & $\begin{array}{c}\Delta \mathrm{FR} \text { is not the Granger reason } \\
\text { for } \Delta \mathrm{RLD}\end{array}$ & 3 & 24 & 5.10110 & 0.01065 \\
\hline \multirow{2}{*}{$\Delta$ RLTL } & $\begin{array}{c}\Delta \text { RLTL is not the Granger } \\
\text { reason for } \Delta \mathrm{FR}\end{array}$ & 3 & 24 & 1.31600 & 0.30180 \\
\hline & $\begin{array}{c}\Delta \mathrm{FR} \text { is not the Granger reason } \\
\text { for } \Delta \mathrm{RLTL}\end{array}$ & 3 & 24 & 3.50068 & 0.03838 \\
\hline \multirow{2}{*}{$\Delta \mathrm{RFI}$} & $\begin{array}{l}\Delta \mathrm{RFI} \text { is not the Granger reason } \\
\text { for } \Delta \mathrm{FR}\end{array}$ & 3 & 24 & 0.34015 & 0.79658 \\
\hline & $\begin{array}{c}\Delta \mathrm{FR} \text { is not the Granger reason } \\
\text { for } \Delta \mathrm{RF}\end{array}$ & 3 & 24 & 0.65857 & 0.58870 \\
\hline
\end{tabular}

3. Relationship of Rural Financial Development Efficiency and Income Growth of Farmers

In accordance with the pulse analysis of VAR model and co-integration equation, based on the negative relationship of rural financial efficiency indicators and farmers' income, this test result is contrary to the financial development efficiency theory that should increase farmers' incomes, but also indirectly 
illustrates the very low efficiency of China's rural credit assignment.

This result is caused by three reasons:

(1) The time series of financial development efficiency have greater volatility in the rural areas. Efficiency of rural finance continued to decline from 1988. From this point of view, the lower rural financial efficiency is an important reason of slow growth of farmers' income.

(2) The "seeks profit" of capital makes it that the deposit-taking financial flows from the rural areas to towns. Rural loans exist only at digital level, and has not effectively delivered to rural areas, which in reality is happening in rural financial sector.

(3) The basic approach is used rural financial directed credit institutions led by the government with subsidized properties in China. Lending target, loan size and loan interest rates are subject to government intervention. Formal rural financial institutions are treated as loan window, rather than demand-driven, full-service agency subject. Government is more concerned about the quality rather than the number of loans. In this government-led credit prescriptive model, the rural credit in rural formal financial institutions is lack of efficiency inevitably.

\section{Conclusions}

In the analysis, the majority of empirical analysis did not join the control variables in their model. Empirical analysis are not considering control variables. As we all know, the factors affecting farmers' income growth include not only financial development. Other important factors test model of farmers' income growth of the lack of impact of the resulting conclusions unconvincing.

\section{References}

[1] Liu D. Practical Analysis of Rural Financial Development Efficiency and Peasants' Income Growth[J]. Journal of Shanxi University of Finance and Economics, 2007, (1): 44-49.

[2] Liu C, et al. Robust $\mathrm{H} \infty$ Control for Satellite Attitude Control System with Uncertainties and Additive Perturbation[J]. International Journal of Science, 2014, 1(2): 1-9.

[3] Ellis F. Rural livelihood diversity in developing countries: evidence and policy implications[M]. London: Overseas Development Institute, 1999.

[4] Evans H E, Ngau P. Rural - Urban Relations, Household Income Diversification and Agricultural Productivity[J]. Development and Change, 1991, 22(3): 519-545.

[5] Liu C, Shi K, Wang F. Mass and mass center identification of target satellite after rendezvous and docking[C]//Intelligent Control and Automation (WCICA), 2014 11th World Congress on. IEEE, 2014: 5793-5798.

[6] Reardon T, Stamoulis K, Balisacan A, et al. Rural non-farm income in developing countries[J]. The state of food and agriculture, 1998, 1998: 283-356.

[7] Mwabu G, Thorbecke E. Rural development, growth and poverty in Africa[J]. Journal of African Economies, 2004, 13(suppl 1): 16-65.

[8] Yaron J, Benjamin M D, Charitonenko S. Promoting efficient rural financial intermediation[J]. The World Bank Research Observer, 1998, 13(2): 147-170. 